\title{
Innovative Service Delivery and Competitive Advantage of Small Scale Hotels in Nigeria: The Moderating Role of Opportunity Connectedness
}

\author{
Cyril, YiltsenTsenyil $^{1 *}$, Samuel, A. Ocholi ${ }^{2}$, Meshach GomamGoyit ${ }^{2}$, Reuel Johnmark Dakung ${ }^{2}$ \\ ${ }^{I}$ Office of the Accountant General, JD Gomwalk Secretariat, Jos-Nigeria \\ ${ }^{2}$ Faculty of Management Sciences, Department of Business Administration, University of Jos-Nigeria
}

*Corresponding Author: Cyril, YiltsenTsenyil, Office of the Accountant General, JD Gomwalk Secretariat, Jos-Nigeria

\begin{abstract}
Firms desire to create competitive advantage to create sustainable value and profitability by implementing innovative service delivery frameworks. This study therefore, tests on the one hand the direct and indirect relationship between opportunity connectedness on the positive relationship between innovative service delivery and competitive advantage of small scale hotels in Nigeria. Using a semi-structured questionnaire on a sample size of 274, the study found through hierarchical regression that there is a significant and positive effect of innovative service delivery and opportunity connectedness on the competitive advantage of small scale hotels in Nigeria. Furthermore, the result revealed a significant and positive moderating role of opportunity connectedness in the relationship between innovative service delivery and competitive advantage. The study recommended that hotels should consider developing innovative service delivery strategies that promote them in the competitive arena and also offer efficient services in order to attract and promote competitive advantage of small scale hotels in Nigeria. In addition, the government should open connection outlets for hotels in Nigeria and also ensure that customers are protected across the country as they patronize the services of hotels.
\end{abstract}

Keywords: Innovative service delivery, opportunity connectedness, competitive advantage, small and medium scale hotels, Nigeria

\section{INTRODUCTION}

The global hospitality sector entered 2017 with a strong appetite for growth. Building on momentum gained in the previous years, renewed investor confidence and pent-up demand for trades propelled growth within the global lodging sector, fuelling an increase in transaction activities and worldwide improvements in hotel operations. Global tourism statistics indicate that the sector had created over \$2 trillion US businesses, accounting for $11.3 \%$ of world consumption in 1997. Its direct contribution to GDP in 2016 was USD2, 306 billion (3.1\% of GDP). This is forecasted to rise by $3.8 \%$ to USD2, 394.2 billion in 2017. Furthermore, the number of hotel units in the graded accommodation sector grew by $26 \%$ between 2005 and 2016, mainly in the USA. While strong post-recession gains appear to be cooling off, the hotel sector is projected to sustain strong $6 \%$ growth throughout2018, setting up the industry to hit a record-breaking $\$ 170$ billion in gross bookings (Eurostat, 2017; Ting, 2017; Dakung \& Maimako, 2016; World Tourism Statistics, 1997). With the 2012 Olympic Games, London remains a strong hotel market. Munich and Moscow's hotel markets continue to be top performers, experiencing high percentage competitiveness in hotel values compared to other European markets in 2013. For instance, Moscow is achieving an average of US $\$ 344,355$ per room, well above the European average of US\$240,307 over the past year (Roth \& Fish bin, 2014). To increase their presence in high-growth markets, the international hotel chains are increasingly venturing into Africa. These international hotel chains' development pipeline in Africa is in Nigeria, with a total of 49 hotels and 7,470 rooms (Dakung \& Maimako, 2016; Ward, 2013).This has led to the nation's tremendous economic growth in the hospitality industry especially in the early 2000.

However, in recent times, the growth rate of small scale hotels in Nigeria is fast declining (estimated at about $7.4 \%$ per annum) due to stiff competition. Also, they are faced with a myriad of challenges 
Innovative Service Delivery and Competitive Advantage of Small Scale Hotels in Nigeria: The Moderating Role of Opportunity Connectedness

ranging from poor energy supply and insecurity to misconstrued internal perception, cynical global perspicacity, flawed hotel classification, poor customer service, little or no standardisation in operations, inconsistent regulatory environment and skilled labour shortages resulting to premature death(Chinedum, Ebere\&Nwakaego, 2017).The increased competition has forced firms (in our case small scale hotels) to think of creating value from limited resources. For instance, in order to gain competitive advantage at 2014 World Cup in Brazil, a number of hotels (Windsor Guanabara Hotel, The Windsor Florida Hotel, Blue Tree Premium, Faria Lima Hotel, The Comfort Nova Paulista Hotel and Burj Al Arab famous Sailboat Hotel in Dubai) all researched to ensure that they offered the best services to their customers (Serravallo, 2015; Troacă \& Bodislav, 2012). Today, owners of small scale hotels in Nigeria have realised that employing competitive strategiesiskey to the success of their operations. In view of that, they are becoming more efficient in resource utilisation by emphasising on new procedures to stay ahead of competitors (Victor, Dagogo \& Odunayo, 2018; Nwosu, 2008a). Again the current challenge of global competition is making the hotels to explore better ways to improve competitiveness. Consequently, those with competitive advantage create more economic value than their rivals. As a result, superior performance reached through the competitive advantage makes them market leaders(Barney \& Hesterly 2010; Porter, Delgado-Garcia, Ketels \& Stern, 2008; Porter, 1985).Giving this scenario, it is obvious thatsmall scale hotels will achieve competitiveness when they innovate and take advantage of the opportunities around them. Based on that, Philip (2011) observed that the most important factors that influence the competitive advantage for firms are innovative service delivery andopportunity connectedness.

According to Neneh and van Zyl (2017), innovativeness entails the introduction of new ideas that allows a firm to improve its product or service offering in order to outsmart rivals. Today, service firms rely on innovation to compete favorably (Sambharya \& Lee, 2014; Lopez, Forestry \& Vazquez, 2013; Bell, 2009). The innovative service delivery is associated with inputs that firms must identify and understand how they relate. Also, innovation contributes to the organization by creating value and the potential for organizational competitive advantage (Leal-Rodriguez et al., 2014; Castro et al., 2013; Montes, Moreno \& Morales, 2005). In view of that, Huang (2016) opined that innovation must be aimed at bringing benefit to the firm.

Indeed Roth and Fishbin (2014) observed that hotels across the globe use the ideas of strategic management theory as well as best practices based on industry-specific experience with trends focusing on innovation. Regardless of the source of innovativeness, the goal is to improve operations, guest service and revenue that translate into competitive advantage. For instance, Coyuga Sustainable Hotel has developed a sustainable entrepreneurial platform, starting in Costa Rica. Chic and Basic have developed hotels in Spain that feature hip design and unusual amenities for customers. The RitzCarlton Hotel has built an upgraded training programme using its core company values. Runtz Hotel has used a wifi-enabled touch screen application to allow guests to efficiently enjoy upscale hotel services. In an attempt to isolate the best strategic management practices common to the leading hotels in the hospitality industry, it has been observed that the main focus is on the customers in terms of creating value, which contributes towards competitive advantage (Dakung \& Maimako, 2016; Ward, 2013; Liyanage, 1999). This is possible through opportunity connectedness.

Opportunity connectedness is used to describe firms' connections to opportunities in either the homemarket network, the host-market network, or the international market network. In this study, opportunity connectedness is viewed as a network of social relations characterized by trust, reciprocity and cohesiveness among operators of small scale hotels. It is a business relationship that is based on a particular business network (i.e., consisting of customers and suppliers). Opportunity connectedness has been viewed as a prerequisite for innovation since it provides access to knowledge and resources that would otherwise be unavailable to individual firms seeking competitiveness (Powell etal., 1996). Hence, this study proceeds from the notion that opportunity connectedness is vital for Small Scale hotels that want to compete even beyond local boundaries (Nordman \& Tolstoy, 2016; Tolstoy \& Agndal, 2010). Similarly, Lindstrand et al. (2011) opined that knowledge about business opportunities acquired from customer and supplier networks in markets can be useful in offering firm competitive advantage.

Prior studies like Neneh and van Zyl (2017), Huang (2016), Leal-Rodriguez et al. (2014), Sambharya and Lee (2014),Castro et al. (2013), Lopez, Forestry and Vazquez (2013), Montes, Moreno and 
Innovative Service Delivery and Competitive Advantage of Small Scale Hotels in Nigeria: The Moderating Role of Opportunity Connectedness

Morales (2005) and Bell (2009) revealed that employing innovative services can promote firm's competitive advantage. Contextually, studies by Ibidunni, Iyiolaand Ibidunni (2014) and Odumeru (2013) indicate that innovation has potential to enhance competitiveness, especially among firms in Nigeria. Similarly, Nordman and Tolstoy (2016) and Tolstoy and Agndal (2010) found that opportunity connectedness is vital for Small Scale hotels that want to compete even beyond local boundaries.However, these studies fail to consider the moderating effect of opportunity connectedness in the relationship between innovative service delivery and competitive advantage, especially among the Small Scale hotels in Nigeria. Thus, the purpose of this paper is to test the moderating effect of opportunity connectedness in the relationship between innovative service delivery and competitive advantage, especially among the Small Scale hotels in Nigeria.

The paper is organized into 7 sections. The next section contains the review of the necessary literature and hypotheses setting. The third section discusses the methodology used in the study, while section four indicates the results and discussions of the findings. Section five focuses on conclusion drawn from the study, and section six concentrates on possible policy recommendations. Lastly, section seven identifies the limitations to the study and areas for future studies.

\section{REVIEW OF LITERATURE AND HYPOTHESES DEVELOPMENT}

\subsection{Concept of Competitive Advantage}

Competitiveness of a firm is its capacity to achieve targets. A firm has competitive advantage when it is able to create more economic value than its rivals do. Competitive advantages are those factors that a firm needs to have in order to succeed in business (Barney \& Hesterly, 2010; Analoui, \& Karami, 2003). There are three types of competitive advantage; the cost of leadership, differentiation and focus (Porter, 1985). Similarly, Lynch (2006) observed that each of these three strategic options represents an area that every business and many not-for-profit organizations can usefully explore and as well choose in order to compete in the marketplace and gain sustainable competitive advantage. He also stated that the general principles can perhaps be applied to public service and not-for-profit organizations where they compete for resources, such as government funding of small scale hotels. Consequently, some strategic management researchers are advocating the importance of competitive advantage or the understanding of firms' market positions from a dynamic theoretical perspective (Lei et al., 1996; Porter, 1991)

Unique competencies help a firm stand out in its markets when its competencies are superior to its competitors (Andrew, 1971). Unique resources are those resources that can create sustained competitive advantage for a firm. These resources are distinctive or unique capabilities specific to particular organizations and cannot be imitated. Core competencies and distinctive competence are two main factors that induce small scale hotels to have a competitive advantage. Core Competences are the skills and abilities by which resources are deployed through the organization's activities and processes in such a way as to achieve competitive advantage in ways that cannot be imitated or obtained by others (Johnson et al., 2010). Competitive advantage therefore is important for businesses. Only the firms with superior performance skills are bestowed with core competencies while another firm needs to acquire them in order to withstand the competition. Not all businesses have a competitive advantage and so it is important for small scale hotels to find a way of obtaining, maintaining and increasing their competitiveness in order to outsmart their rivals.

\subsection{Concept of Innovative Service Delivery}

The capacity for a firm to innovate involves the integration of resources and skills in the business including technology, strategy, knowledge, processes and organisation (Li \& Chen, 2010). This then implies that innovative service delivery essentially is a measure that service delivered meets service users' or clients' expectations. Since innovative service process leads to an outcome in which the customer/client can be either satisfied or dissatisfied with the service experience, it is of great importance that the provider pays attention to designing the system that the service concepts are produced and delivered to clients (Mayer et al., 2003; Brown et al., 1994). It is therefore the role of delivery to ensure that the expected service outcome is received by the client (Goldstein et al., 2002). An innovative service delivery system is made up of multiple, interdependent service processes. Such process involves a sequence of activities and steps, the flows and interactions between these activities, 
Innovative Service Delivery and Competitive Advantage of Small Scale Hotels in Nigeria: The Moderating Role of Opportunity Connectedness

and the resources required for producing and delivering the service outcome (Slack et al., 2004). It involves defining the roles of people, technology, facilities, equipment, layout and processes that generate the service outcome.

The theory of innovation in services developed by Gallouj and Weinstein (1997) has been widely discussed in service innovation literature (Drejer, 2004; Windahl et al., 2004; Tether \& Howells, 2007). Their model constitutes an early attempt to bring together research on product and service innovations which contributes to the "synthesising" stream of service innovation literature. Service innovation can be found in one or several of the following elements: service outcome characteristics (e.g. new ingredient in a dish, new design of final report in consultancy), service provider competencies (new knowledge and new skills), service provider technology (new IT systems, new machines and new procedures), and client competencies (e.g. customer provides information on stock level to supplier). Meaning that for an effective innovative service delivery, the business ought to understand the expectations of clients/customers in order to develop an inclusive service design and service delivery system (Goldstein et al., 2002; Gouillart \& Sturdivant, 1994; Roth \& Menor, 2003). Effective design must therefore ensure that both the service outcome and the process of innovative service delivery are perceived as being of good quality by the clients so as to generate their client satisfaction. This will in turns ensure customer retention and give the businesses leverage to gain and maintain a competitive edge (Verma et al., 2002; Cronin \& Taylor, 1992).

Further, a distinction can therefore be made between quality as the intrinsic value associated with an innovative service product and quality as meeting needs and requirements of the client. This is precisely so since innovative delivery of services is a process based on broadly accepted normative and ethical values and guidelines, emanating from politics, community and social values, as well as other prescribed guidelines (Cloete, 1998). Monitoring quality assurance is a popular tool used to track, evaluate and review innovative service delivery performance. In service delivery reviews, the terms of reference for quality assurance often tend to reflect the service quality and customer satisfaction model and the commodity notion of service delivery. In this way, employees' roles and responsibilities should be clarified and monthly or quarterly workplace plans should relate to the goals and performance standards set for the individuals or teams in the department and the organisation as a whole.

\subsection{Theoretical Underpinning}

This study hinges on social capital theory whose central proposition in this study is opportunity connectedness of Small Scale hotels in competitive advantage equation. The theory is based on the premise that network of social relations characterized by trust, reciprocity and cohesiveness is necessary in facilitating cooperation and competitive advantage of small scale hotels (Jackman \& Miller, 1998; Coleman, 1988). Most entrepreneurs connect themselves with certain networks to gain competitiveness by obtaining relevant information, skills and other resources needed for their business successes. Considering the current study, it can be said that when small scale hotels link well with their customers and suppliers, they are able to compete favourably with other competitors (Nordman \& Tolstoy, 2016; Hanelletal, 2014; Tolstoy \& Agndal, 2010). Adding to that, the interface between small scale entrepreneurs and the environment is important in promoting competitiveness. This is consistent with Bettcher and Mihaylova (2015) and Chris and Graham (2007) who pointed out that social connection are vital for stimulating entrepreneurial activity/competitiveness. Also, opportunity connectedness will help strengthen small scale hotels' chances of competitive leadership in the business arena. This enables them to be exposed to innovative practices while at same time ensuring all-member commitment to change processes that will see through novel actions and competitive advantage.In sum, it is obvious that a firm that is well linked with customers, government and suppliers gains important advantage and benefits of achieving its goals successfully. Arising from this understanding, it is evident that social connections unlock the chances of firms (in our case small scale hotels) in attaining business goal.

\subsubsection{Innovative Service Delivery and Competitive Advantage}

According to Tidd et al. (2007), innovation contributes to achieving a competitive advantage. Similarly, Leal-Rodriguez et al. (2014) found out in their study that innovation contributes to the organisation by creating value. This then means that innovation is an important source of hotels' 
Innovative Service Delivery and Competitive Advantage of Small Scale Hotels in Nigeria: The Moderating Role of Opportunity Connectedness

sustainable competitive advantage, because it leads to service improvements (Castro et al., 2013). The value created through innovation by providing new or unique products and services is significant potential for organisational performance. In a similar vein, Dakung and Maimako (2016), Laforet (2013), Jimenez-Jimenez and Sanz-Valle (2011) and Montes, Moreno and Morales (2005) established that innovation positively affects business performance in terms of competitiveness. Further, Martínde Castro et al. (2013) validated that developing successful technological innovations is essential for creating and sustaining an organisation's competitive advantage. This links well with the findings of Zemplinerová (2010) that the introduction of innovations are the determining characteristics for gaining a dominant part of the market. Supporting this position, Autant-Bernard, Fadairo and Massard (2013) in their survey found the importance of innovation in promoting competitive advantage of a firm. This is supported by results of Noruzy et al. (2012) and Autant-Bernard (2001) who established that the innovative activity of organisations significantly influences competitiveness which is based on inimitable skills and abilities. Therefore, achieving competitiveness by means of innovations means producing less costly products of better quality compared to those manufactured by competitors. Organisation that is not capable of employing innovations will lag behind and the initiative will be taken over by other entities. Schumpeter (1934) as cited in Tidd et al.(2007) asserted that entrepreneurs that attempt to use technological innovation by firms will enable them gain a strategic competitive advantage. For example the use of customer relationship management software gives comprehensive information about customer choice and preference and provides market intelligence. Moreover, small scale hotels that utilise information on customers innovatively will serve their needs best and, consequently, gain competitive advantage (Zemplinerova, 2010; Noorani, 2014; Wilford, 2000).Therefore, we hypothesize that:

$H_{1}$ : Innovative service delivery is significantly and positively related to competitive advantage of Small Scale Hotels in Nigeria.

\subsubsection{Opportunity Connectedness and Competitive Advantage}

As earlier mentioned, opportunity connectedness has to do with a business relationship's dependence on knowledge based opportunities generated by inputs from a particular business network (i.e., consisting of customers, customers' customers, and suppliers).The importance of opportunity connectedness in local settings has been implied in recent articles discussing that international business opportunities emerge more frequently in inter-firm constellations than within the boundaries of individual firms (Freemanetal, 2006; Johanson \& Vahlne, 2009; Tolstoy \&Agndal,2010). Hence, connectedness determines the opportunities that are available and when they become available irrespective of their size. In this study, opportunity connectedness is measured by estimating the extent to which a small scale hotel relationship is anchored on original ideas linked to business relationships (i.e., with other customers, customers' customers, and suppliers).

Based on that, Abbasi et al. (2011) found that entrepreneurial opportunities play a vital role in enhancing firm competitiveness. Similarly, Gunda (2014), Wood and McKinley (2010) and Ozgen and Baron (2007) contended that when firms connect with opportunities around them, it will lead to the better formation of new ventures and their attendant success. Meanwhile, visualising of things that do not so far exist (i.e., business vision), discovering of opportunity, getting them into creation (opportunity exploitation) and the attainment of market acceptance are possibly the most attractive of all successful entrepreneurial activities (Gaglio, 2004). To Kirzner (1997), entrepreneurs who have specific knowledge and utilises it to exploit opportunities will perform better than other competitors. This is strengthened in the studies of Busenitz (1996), Kaish and Gilad (1991) and Timmons and Spinelli (2004), where efficacious entrepreneurs have the ability to comprehend opportunities over others. In addition, Shamudeen, Keat and Hassan (2017) found that knowledge about business opportunities acquired from customer and supplier networks in previous market assignments will offer businesses an edge over others. Similarly, discovering opportunities foster strong ties which are important for the entrepreneur to compete favourably. Therefore, small businesses use the managerial competences to connect to opportunities by means of strong and closed relationship. This in turn enables them to develop competitive advantage. Therefore, we hypothesize that:

$\mathrm{H}_{2}$ : Opportunity connectedness is significantly and positively related to competitive advantage of Small Scale Hotels in Nigeria. 
Innovative Service Delivery and Competitive Advantage of Small Scale Hotels in Nigeria: The Moderating Role of Opportunity Connectedness

\subsubsection{Moderating Role of Opportunity Connectedness}

Even though there is general consensus that opportunity connections matters, it means many things to many people. Individuals and firms are desirous to be connected to three interrelated domains within the society such as the markets, services and spaces. Shane (2003) noted that social connections are important predictors of entrepreneurial success. Better access to novel ways of marshaling resources and information will result to firm competitiveness, which depends on social networks. Not only does research support these connections as being a significant influence on successfully operating a business, it also reveals that firms with stronger social ties will have stronger performing ventures. This suggests that the interface between innovative service delivery of small scale hotels and competiveness depends on a systematic development of networks of entrepreneurs. Furthermore, it is argued that novel approaches to work processes that will result to competitive advantage are created due to collaboration and cooperation among all work members who see themselves as one family. Hence, brainstorming and diversity of opinions, knowledge and backgrounds allow for a thorough airing and assessment of alternatives.

Indeed, when a firm capitalizes on mutual coexistence, it provides the leverage for innovative practices that result to competitiveness. This is consistent with the findings of Chris and Graham (2007) and Sin et al. (2002) that social interaction networks, closeness, friendship, satisfaction and ultimately appeals to member's affection, sense of belonging and pleasurable behavior impacts innovative service delivery. Implicit is the fact that reciprocity as a social occurrence or practice lead to some expected outcomes. This suggests that the innovative-competitive advantage relationship is determined by the social networks that are formed by a firm. Also, the findings of Jobber and Fahy (2006) established that opportunity connectedness is crucial in the relationship between innovation firms' chances and economic advantage. In summary, this provides evidence that small scale hotels that establish network of social relations characterized by trust, reciprocity and cohesiveness will gain important benefits of achieving their goals successfully and easily. Arising from this understanding, it is obvious that opportunity connectedness unlocks the potentials of firms to attain competitive advantage. Consequently, the experience obtained will further strengthen innovation-competitiveness relationship. Hence, stemming from the social capital perspective developed by Coleman et al (1988) and the empirical studies, we set down our hypothesis thus:

$H_{3}$ : Opportunity connectedness moderates the relationship between innovative service delivery and competitive advantage of small scale hotels in Nigeria.

\section{Methodology}

\subsection{Design, Population and Sample Procedure}

The study employs cross-sectional research design to investigate the hypotheses generated in this study. This study was both descriptive and analytical in nature. A total population of 980 managers/CEOs of small scale hotels was used for this study sourced from Plateau State Tourism Cooperation (2017). Thus, from the foregoing, the sample for the study was selected which resulted into a sample of 274 respondents using the formula by Yamane (1973). Thus, a total sample of 274 owners and employees was used for this study in line with Yamane (1973). The study used a semistructured questionnaire to elicit responses from the owners and employees of small scale hotels selected for this study. Prior to the main study, the questionnaire was first subjected to a pilot study before embarking on the final study. After pre-testing the questionnaire, all the negatively worded, ambiguous and difficult questions were deleted in order to have a refined questionnaire for the final field study. The measurement items used in the questionnaires were adopted from earlier studies.

\subsection{Measures of Study Variables}

Innovative service delivery was measured using adapted measure based on those previously employed by Tierney, Farmer, and Graen (1999). The measurement items were adapted from the literature with minor modifications and rewording to ensure contextual consistency. Example of the items are: "our business generates novel ways of operations", "Innovation is supported and rewarded in our business", "our business has new ideas of marketing to customers", "our business always serves as a good role model for doing new things." The respondents were required to indicate their degree of 
Innovative Service Delivery and Competitive Advantage of Small Scale Hotels in Nigeria: The Moderating Role of Opportunity Connectedness

agreement or disagreement with the items generated, anchored on a 5 point likert scale of strongly agree (5), agree (4), not sure (3), disagree (2), and strongly disagree (1).

Opportunity connectedness as a moderating variable was measured using the constructs of interaction, interdependence, and ties. These constructs were adopted from previous scholarly works by Katz et al. (2005); Granovetter (2004); Heikkilä et al. (2009); Okten and Osili (2004); Ahlin and Townsend (2007); Godquin and Quisumbing (2005), who used them in previous studies and were found to be reliable and valid. The items generated under each construct in the questionnaire were anchored onto a 5-point likert scale of strongly agree (5), agree (4), not sure (3), disagree (2), and strongly disagree (1).

Competitive advantage was measured using the items adapted based on Gilley et al. (2004), Argote and Ingram (2000) and Chen et al. (2009). To determine each firm's nonfinancial performance, respondents were asked to rate their firm's research and development (R\&D) outlays, stability/growth of employment, product/process innovations, employee morale/job satisfaction, customer relations, and supplier relations relative to their competitors. Responses are coded on a 5 point likert scale ranging from $1=$ at the very bottom of similar firms in the sector to $5=$ at the very top of similar firms in the sector.

\subsection{Reliability and Validity of Measurement Items}

The internal consistency of the instruments was measured using Cronbach's alpha coefficient (Cronbach, 1951). Validity is concern with the instrument giving actual results of what it claimed to measure (Babbie \& Monton, 2002; Gregory, 1992).Thus, test to determine reliability (internal consistency) of the instrument was carried out. The results revealed that all variables under study had reliability with alpha coefficients above 0.70 as recommended by Nunnally and Bernstein (1994). Innovative service delivery had alpha coefficient of 0.852 with 7 items retained, opportunity connectedness had alpha coefficient of 0.786 with 6 items retained, and finally competitive advantage had alpha coefficient of 0.872 with 8 items retained. In addition, all the variables under study had content validity figure greater than 0.90 with Innovative service delivery yielding (0.94), opportunity connectedness (0.93), and competitive advantage (0.91).

\subsection{Common Method Bias}

According to Podsakoff, MacKenzie, Paine, and Bachrach (2000), common method bias is the main source of errors in research, and should be considered if valid conclusion isto be drawn from any study. In view of that, common method bias is taken care of in order to avoid inflation or deflation of observed relationships between constructs so as to eliminate type I and type II errors in this study (see also Nunnally, 1978). Based on recommendations by Podsakoff, MacKenzie, Lee and Podsakoff (2003), jargons, vocabularies, ambiguous terms and vague words were re-defined before the main study. Therefore, items in the questionnaire used in this study were kept simple, specific, and concise, and double barreled questions were deleted. All items that were included in the instrument for the final study were re-worded for purposes of simplicity and interpretation. However, the 5-point likertscale anchors used at the pre-test stage was retained to avoid alteration in the meaning of the items in the questionnaire. This was done in order to eliminate common method biases.

\subsection{Data Management and Analysis}

Prior to the data analysis, final data collected from the field were confirmed for careless scoring, inaccurate responses, and missing instruments before capturing them into Statistical Package for Social Sciences (SPSS) that was used to analyze the data. Data captured were checked for data entry errors, outliers, missing values, and normality as stipulated by Hair, Anderson, Tatham and Black (2010) and Field (2005). Box plots were used to check whether values with outliers existed in the data, and missing values were checked by running frequencies for all the items included in the final questionnaire. In addition, test for normality was also performed on the final data from the field. The histogram, normal p-p plots, scatter plots, multicollinearity, and homogeneity of variance were used to establish whether the data were normally distributed as recommended by Field (2005). The results indicated that there were no outliers in the final data. However, missing values existed in the data. As the values were missing completely at random (MCAR), linear interpolation method of data replacement was adopted and all the missing values were replaced. Further, the test for normality in 
Innovative Service Delivery and Competitive Advantage of Small Scale Hotels in Nigeria: The Moderating Role of Opportunity Connectedness

the data was achieved since the histogram was bell-shaped and the normal p-p plots had most observed values falling along the straight line. In addition, the scatter plots had all the values falling closer and within the vicinity of each other, thus indicating that the data were normal. Finally, the multicollinearity test using the variance inflation factor (VIF) and tolerance levels revealed that it was not a problem in the data as indicated by variance inflation factor value of 1.542 and 2.111 for innovative service delivery, opportunity connectedness respectively. Thus, this indicated that there was no violation of the rule of thumb (VIF $<4$ and tolerance $>0.2$ ) in testing for multicollinearity as stipulated by Field (2005).

\subsection{Test to Establish Existence of Moderation Effect}

Jose (2008) graphical method and conditions set by Baron and Kenny (1986) were adopted to test for the interaction effect and, thus, explain whether opportunity connectedness moderates the relationship between innovative service delivery and competitive advantage. According to Jose (2008), interaction effect can be confirmed by graphing the mean and the standard deviation with unstandardized coefficients of main effect, moderator, and the interaction term. He further argued that the complementary effect of the variable can be appropriately proved and interpreted based on the slopes of graphs generated by ModGraph. Thus, much as the magnitude of an effect is greater at one level of a variable than at another, it justifies that a significant interaction has occurred (see also Aiken \& West, 1991). Implying that the graph should not be parallel but must have different gradients or slopes for interaction to be significant.

Furthermore, Jose (2008) argued that in testing interaction, the independent variables must be centered (i.e. subtracting the mean from the global independent variable to get marginal mean score) to get the product of the centered variable to generate the interaction term that is used to test for interaction effect through hierarchical regression of independent variable and interaction term on dependent variable. Thus, hierarchical regression was adopted in order to determine the predictive power of independent variable on the dependent variable. Additionally, Baron and Kenny (1986) also recommend that for an interaction to exist, the effect of independent variable on the dependent variable varies as a function of change in the moderator variable. Further, four conditions must also be satisfied. These include: 1) a significant relationship must exist between the independent and dependent variables; 2) a significant relationship must exist between independent and moderator variables; 3) a significant relationship must exist between dependent and moderator variables; and 4) a significant relationship must exist between the independent, moderator, and dependent variables.

\section{FINDINGS AND DISCUSSION}

The study targeted 274 owners and employees of small scale hotels who were randomly sampled to provide responses. Thus, from the study, the results revealed that 94 percent response rate was achieved. This was possible because data collection was carried out through research assistants. They were recruited from the particular areas where the study was carried out in order to solve the problem of non-responses. Similarly, a list of the hotels with their contacts was obtained from Plateau State Tourism Cooperation (2017). This helped the data collection team to easily follow-up on none responses at the end of the study. The demographic characteristics of the sample are indicated in Table 1below.

The main purpose of this article is to test the moderating effect of opportunity connectedness in the relationship between innovative service delivery and competitive advantage of small scale hotels in Nigeria. Besides, Baron and Kenny (1986) assert that 4 conditions, which test for existence of relationships between the independent, moderator, and dependent variables must be achieved before test for interaction effect is carried out. Drawing from this, Pearson correlation analysis was performed to establish the relationships between the variables under this study. The results are indicated in Table 2below.

Table1: Sample characteristics of respondents

\begin{tabular}{|l|l|l|l|}
\hline & & Frequency & Percentage \% \\
\hline Age Group & $18-28$ & 43 & 21.2 \\
\hline & $29-38$ & 77 & 37.9 \\
\hline & $39-49$ & 65 & 32 \\
\hline & $50 \&$ Above & 18 & 8.9 \\
\hline & Total & $\mathbf{2 0 3}$ & $\mathbf{1 0 0}$ \\
\hline
\end{tabular}


Innovative Service Delivery and Competitive Advantage of Small Scale Hotels in Nigeria: The Moderating Role of Opportunity Connectedness

\begin{tabular}{|l|l|l|l|}
\hline Gender & Male & 123 & 60.6 \\
\hline & Female & 80 & 39.4 \\
\hline & Total & $\mathbf{2 0 3}$ & $\mathbf{1 0 0}$ \\
\hline Marital Status & Single & 85 & 41.9 \\
\hline & Married & 89 & 43.8 \\
\hline & Widowed & 19 & 9.4 \\
\hline & Divorced & 10 & 4.0 \\
\hline Period of Operation & Total & $\mathbf{2 0 3}$ & $\mathbf{1 0 0}$ \\
\hline & 1-2 Years & 46 & 22.7 \\
\hline & 3-5 Years & 73 & 36 \\
\hline & 6-9 Years & 45 & 22.2 \\
\hline & 10 Years \& Above & 39 & 19.2 \\
\hline Educational Qualification & Total & $\mathbf{2 0 3}$ & $\mathbf{1 0 0}$ \\
\hline & Primary & 12 & 5.9 \\
\hline & O' Level & 25 & 12.3 \\
\hline & A' Level & 40 & 19.7 \\
\hline & Diploma & 57 & 28.1 \\
\hline & Bachelor's Degree & 44 & 21.7 \\
\hline & Masters & 25 & 13.3 \\
\hline & Total & $\mathbf{2 0 3}$ & $\mathbf{1 0 0}$ \\
\hline
\end{tabular}

Source: Field Survey, 2018

The sample characteristics reveal that $43(21.2 \%)$ fell within the age bracket of $18-28$ years, $77(37.9 \%)$ fell within the age bracket of 29-39 years, 65(32\%) fell within the age bracket of 39-49 years of age, while $18(8.9 \%)$ fell within the age bracket of 50 years and above. This implies that majority of the respondents fall within the age bracket of 29-39 years. Also, males were more $123(60.6 \%)$ than females 80 (39.4). Similarly, 85(41.9\%) were single, 89(43.8\%) were married, 19(9.4\%) were widowed, while $10(4.9 \%)$ were divorced. This implies that majority of the respondents are married. With regards to the period of operation, 46(22.7\%) have operated between 1-2years, 73(36.0\%) 35years, while 45(22.2\%) operated between 6-9 years, while 39(19.2\%) from 10years and above. This implies that majority of the respondents have been operating their businesses between 3 and 5years.Finally, 12(5.9\%) were primary school holders 25(12.3\%) were O' Level holders 40(19.7) were A' Level holders, 57(28.1\%) were Diploma holders, 44(21.7\%) had Bachelor's Degree, $17(8.4 \%)$ had Master's Degree, while $8(3.8 \%)$ for other qualification. This implies that majority of the respondents hold Diploma certificate as their qualification.

\subsection{Correlation Results}

Table2: Correlation Results

\begin{tabular}{|l|l|l|l|l|l|}
\hline Study variables & M & SD & $\mathbf{1}$ & $\mathbf{2}$ & $\mathbf{3}$ \\
\hline Innovative Service Delivery (1) & 3.54 & .61 & $\mathbf{1}$ & & \\
\hline Opportunity Connectedness (2) & 3.62 & .63 & $.314^{* *}$ & $\mathbf{1}$ & \\
\hline Competitive Advantage (3) & 2.97 & .71 & $.125^{* *}$ & $.238^{* *}$ & $\mathbf{1}$ \\
\hline
\end{tabular}

**. Correlation is significant at the 0.01 level (2-tailed)

*. Correlation is significant at the 0.05 level (1-tailed)

The correlation results showed that there is a significant and positive correlation $(r=.125, \mathrm{p}<0.01)$ between innovative service delivery and competitive advantage. This implies that innovative service delivery has a positive relationship with competitive advantage of small scale hotels in Nigeria. This finding is in line with Dakung and Maimako (2016) who observed that values created through innovation by providing new or unique products and services are significant potential for hotels' performance in terms of competitiveness. This confirms hypothesis (H1) set under this study. Further, the Pearson correlation analysis also indicated that opportunity connectedness and competitive advantage are significantly and positively correlated $(\mathrm{r}=.238, \mathrm{p}<0.01)$, thus, satisfying hypothesis $(\mathrm{H} 2)$ of the study. This implies that there is a positive relationship between opportunity connectedness and competitive advantage of small scale hotels in Nigeria. Indeed, a network of social relations characterized by trust, reciprocity and cohesiveness affect competitiveness especially among operators of small scale hotels in Nigeria. Abbasi et al. (2011) argued that entrepreneurial opportunities play a 
Innovative Service Delivery and Competitive Advantage of Small Scale Hotels in Nigeria: The Moderating Role of Opportunity Connectedness

vital role in enhancing firm competitiveness. Similarly, Gunda (2014), Wood and McKinley (2010) and Ozgen and Baron (2007) contended that when firms connect with opportunities around them, it will lead to the better formation of new ventures and their attendant success.

Upon carrying out correlation analysis, hierarchical regression analysis was employed to test for existence of interaction effect between innovative service delivery and opportunity connectedness to cause a change in competitive advantage. The regression analysis results are shown in Table 3 below. The hierarchical regression results in Table 3showed that there is a significant and positive effect of innovative service delivery on competitive advantage $(\beta=.184, p<.05)$, therefore, supporting hypothesis (H1) of the study which, states that innovative service delivery is significantly and positively related to competitive advantage of small scale hotels in Nigeria. This finding is supported by scholars like Leal-Rodriguez et al. (2014) and Tidd et al. (2007) that innovation contributes to achieving a competitive advantage. This then means that innovation is one of the most important sources of hotels' sustainable competitive advantage, because it leads to service improvements. Thus, values created through providing new or unique products and services are significant potential for organisational performance. In a similar vein, Dakung and Maimako (2016), Laforet (2013), JimenezJimenez and Sanz-Valle (2011) and Montes, Moreno and Morales (2005) established that innovation positively affects business performance in terms of competitiveness. Further, Martín-de Castro et al. (2013) validated that developing successful technological innovations is essential for creating and sustaining an organisation's competitive advantage. This is supported by results of Noruzy et al. (2012) and Autant-Bernard (2001) that the innovative activity of organisations significantly influences competitiveness which is based on inimitable skills and abilities. Therefore, achieving competitiveness by means of innovations means producing less costly products of better quality compared to those manufactured by competitors. Small scale hotel entrepreneurs that attempt to use technological innovation will gain strategic competitive advantage. For example the use of customer relationship management software gives comprehensive information about customer choice and preference and provides market intelligence.

Table3: Testing for Interaction Effects of Innovative Service Delivery and Opportunity Connectedness on Competitive Advantage

\begin{tabular}{|l|l|l|l|l|}
\hline \multicolumn{5}{|l|}{ Dependent Variable: Competitive Advantage } \\
\hline & Model 1 & Model 2 & Model 3 & VIF \\
\hline Constant & 4.570 & 2.447 & 3.242 & \\
\hline Gender & -.050 & .064 & -.055 & \\
\hline Period of Operation & .025 & .039 & .045 & \\
\hline Innovative Service Delivery (Main effect) & $.184^{*}$ & $.135^{*}$ & $.174^{*}$ & 1.542 \\
\hline Opportunity Connectedness (Moderator) & & $.133^{*}$ & $.248^{*}$ & 2.111 \\
\hline Interaction Term & & & $.256^{*}$ & 2.111 \\
\hline & & & & \\
\hline $\mathrm{R}^{2}$ & .055 & .138 & .291 & \\
\hline$\Delta \mathrm{R}^{2}$ & & .083 & .153 & \\
\hline$\Delta \mathrm{F}$ & 7.298 & $8.120^{*}$ & $9.332^{*}$ & \\
\hline Durbin Watson & 1.873 & & & \\
\hline
\end{tabular}

$* * \mathrm{P}<.001 ; \mathrm{n}=274$

In addition, the results from the hierarchical regression also indicated that opportunity connectedness significantly and positively affects competitive advantage $(\beta=.133, \mathrm{p}<.05)$. This lends support to hypothesis (H2) of the study. This finding is in line with Abbasi et al. (2011) that entrepreneurial opportunities play a vital role in enhancing firm competitiveness. Similarly, Gunda (2014) and Ozgen and Baron (2007) contended that when firms connect with opportunities around them, it will lead to the better formation of new ventures and their attendant success. Meanwhile, visualisation of things that do not so far exist (i.e., business vision), discovering of opportunity, getting them into creation (opportunity exploitation) and the attainment of market acceptance are possibly the most attractive of all successful entrepreneurial activities (Gaglio, 2004). To Kirzner (1997), entrepreneurs who have specific knowledge and utilises it to exploit opportunities will perform better than other competitors. This is strengthened in the study of Shamudeen, Keat and Hassan (2017) that corroborated that knowledge about business opportunities acquired from customer and supplier networks in previous market assignments will offer businesses an edge over others. This then means that the discovering 
Innovative Service Delivery and Competitive Advantage of Small Scale Hotels in Nigeria: The Moderating Role of Opportunity Connectedness

opportunities by small scale hotel in Nigeria foster strong ties which are important for the entrepreneur to compete favourably.

More so, the hierarchical regression results revealed a significant and positive moderating role of opportunity connectedness in the relationship between innovative service delivery and competitive advantage $(\beta=.256, \mathrm{p}<.05)$. The results indicated that the moderating role of opportunity connectedness boost the main effect of innovative service delivery in explaining competitive advantage by 15.3 percent $\left(\Delta \mathrm{R}^{2}=0.153\right)$. Indeed, when the interaction term between innovative service delivery and opportunity connectedness is included in the model, the predictive power of innovative service delivery on competitive advantage increases by 15.3 percent from 13.8 percent to 29.1 percent. Thus, the results imply that the interaction term boost the main effect to explain variation in competitive advantage of small scale hotels in Nigeria. This provides support for hypothesis (H3) of the study, which states that opportunity connectedness moderates the relationship between innovative service delivery and competitive advantage of small scale hotels in Nigeria.

Conclusively, it can be deduced that inclusion of opportunity connectedness in the relationship between innovative service delivery and competitive advantage explains 15.3percent variation incompetitive advantage of small scale hotels in Nigeria. Based on this fact, Wood and McKinley (2010) argued that novel approaches to work processes that will result to competitive advantage are created due to collaboration and cooperation among all work members who see themselves as one family. Indeed when a firm capitalizes on mutual coexistence, it provides the leverage for innovative practices that results to competitiveness. This is consistent with the findings of Chris and Graham (2007) and Jobber and Fahy (2006) that social interaction networks, closeness and innovative work behavior results to competitive advantage. Implicit is the fact that reciprocity as a social occurrence or practice lead to some expected outcomes. This suggests that the innovative-competitive advantage relationship is determined by the social networks that are formed by a firm. Hence, small scale hotels in Nigeria that establish network of social relations characterized by trust, reciprocity and cohesiveness will gain important benefits of achieving their goals success easily. Arising from this understanding, it is obvious that opportunity connectedness unlocks these firms to attain competitive advantage. Consequently, the experience obtained will further strengthen innovation-competitiveness relationship.

Finally, Jose (2008) recommends that the interaction effect of the moderator be plotted on a ModGraph to show its impact on the dependent variable. Thus, the results in Table 3above can be plotted to confirm the interaction effect of social networks in the relationship between innovative service delivery and competitive advantage. This is done by plotting the mean and standard deviation with unstandardized coefficients of main effects (innovative service delivery), moderator (opportunity connectedness), and the interaction term on the ModGraph.

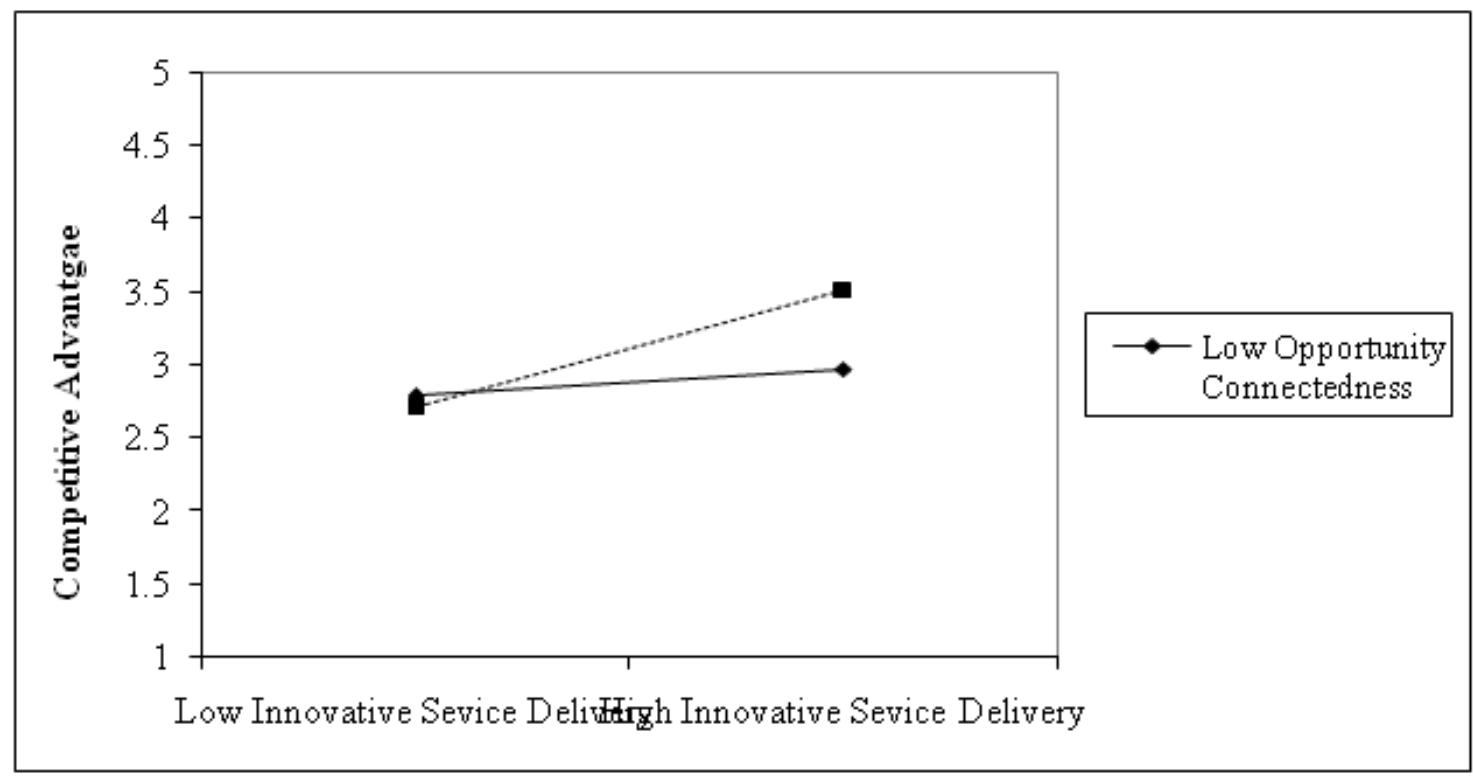

Figure1: ModGraph Showing the Interaction Effect 
Innovative Service Delivery and Competitive Advantage of Small Scale Hotels in Nigeria: The Moderating Role of Opportunity Connectedness

Consequently, as a rule of thumb, Jose (2008) demands that the graphs should not be parallel but must have different gradients or slopes for interaction to be significant. Thus, after plotting the mean and standard deviation with unstandardized coefficients of main effects as indicated in Figure 1, the results indicated that there is an interaction effect between innovative service delivery and opportunity connectedness on competitive advantage since the lines are not parallel. This means that a change in opportunity connectedness significantly affect variations in innovative service delivery in an attempt to influence competitive advantage of small scale hotels. The result lends support to hypothesis (H3) of the study. Further, the ModGraph results can be interpreted based on low and high levels based on the main effects and the moderator (Jose, 2008). Thus, the results showed that the rule for conditional effect is not violated since all the lines are not parallel to each other, thus, showing interactions between innovative service delivery, opportunity connectedness and competitive advantage.

\section{CONCLUSION DRAWN FROM THE STUDY FINDINGS}

Drawing from the hypotheses developed under this study, the following are the conclusion. The findings from the study revealed that there is a significant and positive relationship between innovative service delivery and competitive advantage. This implies that innovative service delivery has an impact on competitive advantage of small scale hotels in Nigeria suggesting that a change in innovative service delivery results into a change in competitive advantage. This is in line with hypothesis (H1) set under this study. Furthermore, the findings also indicated that opportunity connectedness has a significant and positive effect on competitive advantage. This lends support to our hypothesis (H2) of the study. This implies that existence of opportunity connectedness result into competitive advantage of small scale hotels in Nigeria.

Besides, the findings showed that opportunity connectedness significantly and positively moderates the relationship between innovative service delivery and competitive advantage. The results indicated that the interaction effect boost the main effect of innovative service delivery in explaining competitive advantage by 15.3 percent $\left(\Delta \mathrm{R}^{2}=0.153\right)$. Conclusively, it can be deduced that including opportunity connectedness in the relationship between innovative service delivery and competitive advantage explains 15.3 percent variation in competitive advantage of small scale hotels in Nigeria thus, confirming hypothesis (H3) of the study.

\section{RECOMMENDATIONS BASED ON THE STUDY FINDINGS}

Hotels should consider developing innovative service delivery strategies that promote them in the competitive arena. They should also ensure that they offer efficient services in order to attract and promote competitive advantage of small scale hotels in Nigeria. For instance, they should employ a wifi-enabled touch screen application to allow guests to efficiently enjoy upscale hotel services. The government should ensure that there is effective law to enhance standardized operations of hotels in Nigeria. In addition, the government through its Tourism and Hospitality Regulatory authority (Federal Ministry of Tourism) should ensure that customers are protected across the country as they patronize the services of hotels. In addition, hotels should use existing and new social connections in both rural and urban centers to attract more customers to patronize their services. Government should open connection outlets for hotels in Nigeria to enable them compete favourably with foreign based hotels.

\section{LIMITATIONS AND AREAS FOR FURTHER STUDY}

The study relies solely on quantitative data and the findings are based specifically on cross-sectional research design, thus, ignoring qualitative data and longitudinal survey design. Future research may adopt qualitative data and data collected through longitudinal study design. In addition, the study was conducted on small scale hotels in the Nigerian city centers. Other small scale hotels (population) such as the ones in the rural areas may be used as samples in future studies.

\section{REFERENCES}

[1] Abbasi, A., Altmann, J., and Hossain, L. (2011). Identifying the effects of co-authorship networks on the performance of scholars: A correlation and regression analysis of performance measures and social network analysis measures. Journal of Informetrics, 5(4), 594-607.

[2] Abiodun, E. A. and Harry, E. (2014). SME firm performance in Nigeria: Competitive advantage and its impact, International Journal of Research Studies in Management, 3(2), 75-86. 
Innovative Service Delivery and Competitive Advantage of Small Scale Hotels in Nigeria: The Moderating Role of Opportunity Connectedness

[3] Acquaah, M. (2012). Social networking relationships, firms-specific managerial experience and firm performance in a transition economy: a comparative analysis of family owned and nonfamily firms. Research notes and commentaries. Strategic Management Journal, 33, 12151228.

[4] Ada, E., Kazancoglu, Y. and Sagnak, M. (2013). Improving Competitiveness of Small and Medium-Sized Enterprises (SMEs) in Agriproduct Export Business through ANP: The Turkey Case, Agribusiness, 29(4), 524-537.

[5] Agyei-Mensah, B. K. (2011). Financial management practices of small firms in Ghana: An empirical study. African Journal of Business Management, 5(10), 3781-3793.and the Entrepreneur Postulates and Patterns for Entrepreneurial History, Cambridge, MA: Harvard University Press.

[6] Ahlin, C. and Townsend, R. M. (2007). Selection into and across contracts: theory and field research-, Journal of Econometrics, 136(2), 665-98.

[7] Akerlof, G. A. (1970).The Market for "Lemons": Quality Uncertainty and the Market Mechanism, The Quarterly Journal of Economics, 84(3), 488-500.

[8] Amin, M.E. (2005) Social Science Research Conception, Methodology and Analysis. Makerere University Press, Kampala.

[9] Analoui, F. and Karami, A. (2003). Strategic Management. In small and Medium Enterprises. Thomson Learning 203

[10] Andrews, K. R. (1971). The Concept of Corporate Strategy, Dow Jones-Irwin, Homewwod, IL.

[11] Andriessen, D. and Tissen, R. (2001). Weightless Wealth; find your real value in a future of intangible assets, Financial Times Prentice Hall, London.

[12] Antonia Ruiz Moreno, Víctor García Morales, and Francisco Javier Lloréns Montes, L. (2005). "Learning during the quality management process: Antecedents and effects in service firms", Industrial Management \& Data Systems, 105(8), 1001-1021

[13] Argote, L. and Ingram, P. (2000). "Knowledge transfer: a basis for competitive advantage in firms", Organizational Behavior and Human Decision Processes, 82(1), 150-69.

[14] Augier, M and Teece, J. (2009) Dynamic Capabilities and the Role of Managers in Business Strategy and Economic Performance, Organization Science, 20(2), 410-421.

[15] Autant-Bernard, C. (2001). Science and knowledge flows: Evidence from the French case. Research Policy, 30(7), 1069-1078.

[16] Autant-Bernard, C., Fadairo, M. and Massard, N. (2013). Knowledge diffusion and innovation policies within the European regions: Challenges based on recent empirical evidence. Research Policy, 42 (1), 196-210.

[17] Babbie E, Mouton, J. (2007). The Practice of social research, Oxford University Press Southern Africa: Cape Town 2.

[18] Balkin, D. B., Markman, G.D. and Gomez-Mejia, L.R. (2000). Is CEO pay in high-technology firms related to innovation? Academy of Management Journal, 43(6), 1118-1129.

[19] Barney, J. (1991). Firm Resources and Sustained Competitive Advantage, Journal of Management, 17(7).

[20] Barney, J. (1991). Organizational Culture: can it be a source of Competitive advantage? Academy of Management Review, 11(3), 656-665.

[21] Barney, J. B. and Hesterly, W. S. (2010). Strategic Management and Competitive Advantage Concepts.Upper Saddle River, NJ: Pearson Prentice Hall.

[22] Bell, M. (2009) Innovation Statistics and Innovation System Models: Policy Tools and Policy-making in Developing Countries, STEPS Working Paper 34, Brighton: STEPS Centre.

[23] Bergmann Liechtenstein, B. M., and Brush, C. G. (2001). How Do Resource Bundles Develop and Change in New Ventures? A Dynamic Model and Longitudinal Exploration.' Entrepreneurship Theory and Practice 25 (3), 37-59.

[24] Bessant, J. and Tidd, J. (2007) Innovation and entrepreneurship, Chichester, UK: John Wiley \& Sons.

[25] Bettcher, K. and Mihaylova, T. (2015). Economic Inclusion: Leveraging Markets and Entrepreneurship to Extend Opportunity, Center for International Private Enterprise, 1211 Connecticut Avenue, NW, Suite 700.

[26] Biggs, T., Raturi, M., \& Srivastava, P. (2002). Ethnic networks and access to credit: Evidence from the manufacturing sector in Kenya. Journal of Economic Behavior and Organization, 49, 473-486.

[27] Bontis, N. (1996), 'There's a price on your head: managing intellectual capital strategically', Business Quarterly, summer, 60(4), pp. 41-47.

[28] Bontis, N., Keow, W. C. C., \& Richardson, S. (2000). Intellectual capital and business performance in Malaysian industries. Journal of Intellectual Capital, 1(1), 85-100. 
Innovative Service Delivery and Competitive Advantage of Small Scale Hotels in Nigeria: The Moderating Role of Opportunity Connectedness

[29] Briggs, B. R. (2009). Issues affecting Ugandan indigenous entrepreneurship in trade. AfricanJournal of Business Management. 3(12), 786-797.

[30] Burt, R. S. (1992). Structural Holes: The Social Structure of Competition. Cambridge, MA: Harvard University Press Networks 5(1): 13-49.

[31] Busenitz, L.W. (1996), Research on entrepreneurial alertness, Journal of Small Business Management, 34(4), 35-40.

[32] Campbell, D. T. and Fiske, D. W. (1959). Convergent and discriminant validation by the multitraitmultimethod matrix. Psychological Bulletin, 56(2), 81-105.

[33] Carmines, E.G. and Zeller R.A. (1979) Reliability and validity assessment, Newbury Park: Sage Publications.

[34] Castro, G. M., Delgado-Verde, D., Navas-López, J. and Cruz-González, J., (2013) The moderating role of innovation culture in the relationship between knowledge assets and product innovation, Technological Forecasting \& Social Change, 80, 351-363

[35] Cater, T. and Alfirevic, N. (2003). Sources of Competitive Success of Large Enterprises in Transition: The case of Croatia and Slovenia. In: Enterprise in Transition: 5th International Conference, Tučepi, 22-24 May 2003, Faculty of economics, Split, 2372-2392.

[36] Chadwick, C. and Dabu, A. (2009). Human resources, human resource management, and the competitive advantage of firms: Toward a more comprehensive model of causal linkages. Organization Science, 20(1), 253-272.

[37] Chang, W.S. and Hsieh, J.J. (2011). Intellectual Capital and Value Creations: Innovation Capital a Missing Link? International Journal of Business and Management, 6(2), 3-12

[38] Chen, C.J. and Huang, J.W. (2009) 'Strategic human resource practices and innovation performance: The mediating role of knowledge management capacity', Journal of Business Research,62(1), 1041114

[39] Chen, Y. S., Lin, M. J. J. and Chang, C. H. (2006). The influence of intellectual capital on new product development performance-the manufacturing companies of Taiwan as an example, Total Quality Management, 17(10), 1323-1339

[40] Cheng, M.Y., Lin, J.Y., Hsiao, T.Y. and Lin, T.W. (2010). Invested Resource, Competitive Intellectual Capital, And Corporate Performance, Journal of Intellectual Capital, 11(4), 433-450.

[41] Chinedum, N., Ebere, O. R. and Nwakaego, C. J. (2017). Diagnostics of Customer Satisfaction in the Hospitality Industry: Evidence from Nigeria, British Journal of Marketing Studies, 5(1), 68-77

[42] Chris, A. O. (2007). Cultural Diversity Management and Organizational Performance: A Theoretical Paradigm. West African Journal of Business, 9(2), 114-41.

[43] Clark, L. A. and Watson, D. (1995). Constructing validity: Basic issues in objective scale development,Psychological Assessment, 7(3),309-319.

[44] Click, R. and Duening, T. (2005). Business Process Outsourcing the Competitive Advantage.

[45] Cloete, J. J. N. (1998). South African public administration and management. Pretoria: Van Schaik Publishers.

[46] Cook, R., Campbell, D., \& Kelly, C. (2012). Survival Rates of New Firms:An Exploratory Study, Small Business Institute Journal, 8(2), 35-42.

[47] Cook, T. D. and Campbell, D.T. (1979). Quasi- experimentation: Design and analysis issues for field settings. Chicago: Rand McNally.

[48] Cronin, J. J. and Taylor, S. A. (1992). Measuring service quality: A re-examination and extension, Journal of Marketing, 56(3), 55.

[49] Cruz Basso L. F., Kimura H. and De Aguiar, J. F. (2010). Intellectual capital and value creation in the production and assembly of vehicles and auto-parts sector in Brazil: panel data analysis,Journal of Modern Accounting and Auditing 6(8), 15-25.

[50] Dababneh, R. and Tukan, F. (2007). Booklet of standardized small and medium enterprises definition2007. Washington D.C.: A publication of USAID.

[51] Dakung, R. J. (2009). Building an innovative Enterprise in Entrepreneurial Skill Development: A practical Approach. Jos: Eriba Press, Nigeria.

[52] Dakung, R. J., Orobia, L., Munene, J. C. and Balunywa, W. (2017). The Role of Entrepreneurship Education in Shaping Entrepreneurial Action of Disabled, Journal of Small Business \& Entrepreneurship, 29(4).

[53] Dakung, R. J. and Maimako, S. S. (2015). An Assessment of Intellectual Research and Innovation Management Practices in Nigerian Hospitality Industry: A study of selected Hotels in Jos Plateau State, West African Journal of Research and Innovation Management (WAJORIM), 1(1): 66-81 
Innovative Service Delivery and Competitive Advantage of Small Scale Hotels in Nigeria: The Moderating Role of Opportunity Connectedness

[54] De Vellis, R. F. (2003) Scale development: theory and applications, 2nd ed., London, Sage.

[55] De Wit S, Niry D, Wariyar R, Aitken M.R.F. and Dickinson A. (2007). Stimulus outcome interactions during conditional discrimination learning by rats and humans. J Exp Psychol Anim Behav Process,33(1):1-11.

[56] Dierickx, I. and Cool, K. (1989) 'Asset stock accumulation and sustainability of competitive advantage', Management Science, 35(12), 1504-1511.

[57] Diez, J. M., Ochoa, M. L., Prieto, M. B. and Santidrian, A. (2010). Intellectual capital and value creation in Spanish firms, Journal of Intellectual Capital, 11(3), 348-367.

[58] Dixit, A.K. (1980). The role of investment in entry deterrence. Vol. 90, pp. 95-106

[59] Duval-Couetil, N., Kisenwether, E., Tranquillo, J., Wheadon, J. (2014, June). Catalyzing the Adoption of Entrepreneurship Education in Engineering by Aligning Outcomes with ABET. Proceedings of the American Association of Engineering Education Annual Conference, Indianapolis, IN.

[60] Edvinsson, L. and malone, M. S. (1997). Intellectual capital: realizing your company's true value by finding its hidden brainpower, New York, Harperbusiness.

[61] Eisenhardt, K. M., and Martin, J. A. (2000). Dynamic capabilities: What are they?Strategic Management Journal, 21(10), 1105-1121.

[62] Ellison, N., Steinfield, C. and Lampe, C. (2007). The benefits of Facebook "friends": Exploring the relationship between college students' use of online social networks and social capital,Journal of Computer-Mediated Communication, 12(3).

[63] Eries, E. D., and Saatcioglu, O.Y. (2006). A system look for technological innovation: based perspective. In: European and Mediterranean conference on systems (EMCIS). Costa Balance, Alicante, Spain.

[64] Ferchichi, J., and Paturel, R., (2013). The effect of intellectual capital disclosure on the value creation: an empirical study using Tunisian annual reports, International Journal of accounting and Financial Reporting 3(1), 81-107.

[65] Floro, S. L. and Yotopolous, P. A. (1991). Informal credit markets and the new institutional economics: The case of Philippine agriculture (p. 1991). Boulder: Westview Press

[66] Gaglio, C.M. (2004). The role of mental simulations and counterfactual thinking in the opportunity identification process, Entrepreneurship Theory and Practice, 28(6), 533-552.

[67] Gallouj, F. and Weinstein, O. (1997). "Innovation in services”, Research Policy, 26, 537-56.

[68] Gilley, K.M., Greer, C.R. and Rasheed, A.A. (2004) Human Resource Outsourcing and Organisational Performance in Manufacturing Firms, Journal of Business Research, 57, 232-240

[69] Goh, P. C., \& Lim, K. P. (2004). Disclosing intellectual capital in company annual reports: evidence from Malaysia. Journal of Intellectual Capital, 5(3), 500-510.

[70] Goldstein, S. M., Johnston, R., Duffy, J. and Rao, J. (2002). "The service concept: the missing link in service design research?"Journal of Operations Management, 20(2), 121-134.

[71] Gouillart, F.J. and Sturdivant, F. D. (1994). Spend a Day in the Life of Your Customers, Harvard Business Review, 72(1), 116.

[72] Granovetter, M. S. (1973). The strength of weak ties, American Journal of Sociology, 78, 1360-1380.

[73] Granovetter, M. S. (2004). The impact of social structure on economic outcomes, Journal of Economic Perspectives, 19, 33-50.

[74] Grant, R. (1991). The outsourcing of IT-enabled business processes: A conceptual model of the location decision, Journal of International Management, 11(2), 253-268.

[75] Gunda, M.S. (2014). Opportunity Recognition Levels among IT Entrepreneurs in South Africa (Doctoral Dissertation), University of the Witwatersrand.

[76] Harris, C. and Vickers, J. (1985). "Perfect equilibrium in a model of a race." Review of economic studies, vol. 52, 193-209.

[77] Harris, O. and Sauzer, D. (2006). The contribution of small scale industries to the national economy, Standard research journal of business management, 1(2), 60-71.

[78] Heikkilä, A., Kalmi, P. and Ruuskanen, O. P. (2009). Social capital and access to credit: Evidence from Uganda. Helsinki: Department of Economics, Helsinki School of Economics and HECER.

[79] Heikkilä, J. and Cordon, C. (2002). Outsourcing: a core or non-core strategic management decision, Strategic change, 11(11), 183-193.

[80] Hermans, R., and Kauranen, I., (2005). Value creation potential of intellectual capital in biotechnologyempirical evidence from Finland, R\&D Management 35, 2, 171-185. 
Innovative Service Delivery and Competitive Advantage of Small Scale Hotels in Nigeria: The Moderating Role of Opportunity Connectedness

[81] Hurley, R. F. and Hult, G. T. M. (1998). Innovation, market orientation, and organizational learning: An integration and empirical examination, Journal of Marketing, 62(3), 42

[82] Hurtado- Ayala, A. and Gonzalez-Campo, C. H. (2015). Measurement of knowledge absorptive capacity: An estimated indicator for the manufacturing and service sector in Colombia, Journal of globalization, competitiveness and governance, 9(2):16-42.

[83] Huyghebaert, N. and L. M. Van de Gucht. (2004). The determinants of financial structure: New insights from business start-ups, European Financial Management, 13(1), 101-133.

[84] Ibidunni, O. S., Iyiola, O. and Ibidunni, A. S. (2014). Product innovation, a survival strategy for small and medium enterprises in Nigeria, European Scientific Journal, 10(1), 194-209.

[85] Ismail, K. and Haider, M. (2015). Can Intellectual Capital of SMEs Help in Their Sustainability Efforts? Journal of Management Research.

[86] Jimenez- Jimenez,D. and Sanz-Valle, R. (2013) Studying the Effect of HRM Practices on the Knowledge Management Process, Personnel Review, 4228-49.

[87] Jimenez-Jimenez, D. and Sanz-Valle, R. (2011). Innovation, organizational learning, and performance, Journal of Business Research, 64(4), 408-417.

[88] Johanson, J. and Vahlne, J. E. (2009). The Uppsala internationalization process model revisited: From liability of foreignness to liability of outsidership. Journal of international business studies, 40(9), 14111431.

[89] Johnson, S. G., Webber, D. J. and Thomas, W. (2010). Which SMEs use External Business Advice? A multivariate sub-regional study, Environment and Planning A, 39(8), 1981-1997.

[90] Joseph, E. S. (1996). The World Bank Research Observer, 11(2), 151-177.

[91] Kaish, S. and Gilad, B. (1991). Characteristics of opportunities search of entrepreneurs versus executives: Sources, interests, general alertness, Journal of Business Venturing, 6(1), 45-61.

[92] Kamukama, N. and Sulait, T. (2017). "Intellectual capital and competitive advantage in Uganda's microfinance industry," African Journal of Economic and Management.

[93] Kamukama, N., Ahiauzu, A. and Ntayi,J.M.(2011). Competitive advantage: mediator of intellectual capital and performance, Journal of Intellectual Capital. 12(1), 152-164.

[94] Kang, R. Li, X. Yang, T. Xiao, (2007)."Reducing the power consumption in the EL displays", Proc. Asia Display, 450-454.

[95] Karlan, D. S. (2007). Social connections and group banking, The Economic Journal, 117(517).

[96] Katz, M.L. (1986). “An analysis of cooperative research and development.” RAND journal of economics, $17,537-543$

[97] Katz, N., Lazer, D., Arrow, H. and Contractor, N. S. (2005). Applying a network perspective to small groups: Theory and research. In M. S. Poole \& A. B. Hollingshead (Eds.), Theories of small groups: An interdisciplinary perspective. Newbury Park, CA: Sage.

[98] Khalique, M., \& Isa, A. H. M. (2014). Intellectual capital in SMEs operating in boutique sector in Kuching, Malaysia. The IUP Journal of Management Research, 8(2), 17-28.

[99] Khan, M. W. J. Identifying the Components and Importance of Intellectual Capital in KnowledgeIntensive Organizations, Business and Economic Research, 4(2) (2014) 297.

[100] Kim, T. Y., Hon, A. H. Y. and Crant, M. (2009). Proactive personality, employee creativity, and newcomer outcomes: A longitudinal study, Journal of Business and Psychology, 24, 93 - 103.

[101] Kirzner, I. M. (1997). Entrepreneurial Discovery and the competitive Market process: An Austrian Approach, Journal of Economic Literature, 60-85.

[102] Kotabe, M., Jiang, C. X. and Murray, J. Y. (2011). Managerial Ties, Knowledge Acquisition, Realized Absorptive Capacity And New Product Market Performance Of Emerging Multinational Companies: A Case Of China, Journal of World Business, 46:166-176.

[103] Kothari, C.R. (2004) Research Methodology Methods and Techniques. 2nd Edition, New Age International Publishers, New Delhi.

[104] Krejcie, R. V. and Morgan, D. W. (1980). Determining sample size for research activities, Educational \& Psychological Measurement, 30, 607-610.

[105] Kritikos, A. S (2014). Entrepreneurs and their impact on jobs and economic growth: Productive entrepreneurs can invigorate the economy by creating jobsand new technologies, and increasing productivity: DIW Berlin, University of Potsdam, and IZA, Germany.

[106] La Rocca, M., La Rocca, T. and Cariola, A., (2008). Corporate governance, intellectual capital and value creation, The ICFAI University Journal of Corporate Governance 7(3), 7-30. 
Innovative Service Delivery and Competitive Advantage of Small Scale Hotels in Nigeria: The Moderating Role of Opportunity Connectedness

[107] Lacroix, M. and Zambon, S., (2002). Capital intellectual et creation de valeur: une lecture conceptuelle des pratiques française et italienne, Comptabilité -Contrôle -Audit, numéro spécial, Mai, 61-84.791

[108] Laere, K. V. and Heene, A. (2003). Social Networks as a Source of Competitive Advantage for the Firm, Journal of Workplace Learning, 15(6), 248-258.

[109] Laforet, S. (2013). Organizational innovation outcomes in SMEs: Effects of age, size and sector, Journal of Business World, 48(4), 490-502.

[110] Leal-Rodriguez, A., Ariza-Montes, J.A., Roldan, J.L. and Leal-Millan, A.G.L. (2014). Absorptive capacity, innovation and cultural barriers: A conditional mediation model, Journal of Business Research, 67(5), 763-768.

[111] Lechner, C. and Gudmundsson, S. V. (2012). Entrepreneurial orientation, firm strategy and small firm performance. International Small Business Journal.

[112] Lei, D., Hitt, M.A. and Bettis, R. (1996). Dynamic Core Competences through Meta-Learning and Strategic Context, Journal of Management, 22, 549-569.

[113] Liao, S., Fei, W. and Liu, C. (2008). Relationship between knowledge inertia, organizational learning and organization innovation, Technovation, 28(4), 183-195.

[114] Li and Chen. (2010). The effects of Innovation Capacity on New Product Development Performance: the evidence of Zhejiang Province' SMEs. Management and Service Science (MASS), International Conference, 1, 5, 24-26.

[115] Lin, Y. and Chen, M. Y. C. (2007). "Does Innovation Lead to Performance? An Empirical Study of SMEs in Taiwan," Management Research News, 30 (2), 115-132.

[116] Lindstrand, A., Melén, S. and Nordman, E. R. (2011). Turning social capital into business: A study of the internationalization of biotech SMEs, International Business Review, 20(2), 194-212.

[117] Lippman, S.A. and Rumelt, R.P. (1982), Uncertain Imitability: An Analysis of Interfirm Differences in Efficiency under Competition, Bell Journal of Economics, 13, (2), 418-438

[118] Long, C. and Vickers-Koch, M. (1995). Using core capabilities to create competitive advantage, Organisational Dynamics, 24:6-22.

[119] López et al. (2013). What a company needs to innovate? Research, experience and persistence, European Journal of Management and Business Economics, 266-281.

[120] Mahoney, J. T., \& Pandian, J. R. (1992). The resource- based view within the conversation of strategic management, Strategic Management Journal, 13, 363-380.

[121] Makovec-Brencic, M., \& Zabkar, V. (2001). Competitive Advantage as a Result of Non-price Factors: Application of the Structural Equation Model, Economic and Business Review, 3(1), 25-34.

[122] Martín-deCastro, G., Delgado1Verde, M., López1Sáez, P. and Navas1López, J. E. (2011). 'Towards 'an intellectual capitallbased view of the firm': origins and nature', Journal of Business Ethics, 98(4), 649662.

[123] Mayer, K. J., Bowen, J. T. and Moulton, M. R. (2003). "A proposed model of the descriptors of service process", Journal of Services Marketing, 17(6), 621-639.

[124] Mazanai, M. and Fatoki, O. (2012). Access to finance in the SME sector: A South African perspective, Asian Journal of Business Management, 4(1), 58-67.

[125] McGrath, R. and Sparks W. (2006). Knowledge, Social Capital and Organizational Learning, International journal of the management, 27-29.

[126] Montes, F. J. L., Moreno, A. R. and Morales, V. G. (2005). Influence of support leadership and teamwork cohesion on organizational learning, innovation and performance: an empirical examination, Technovation, 25(10), 1159-1172.

[127] Mishkin, F. (2007). Housing and monetary transmission mechanism (Federal Reserve Board Finance and Economics Discussion Series, No. 40). Jackson: Federal Reserve Bank of Kansas City.

[128] Muhos, M. and Sanpanich, S. (2009). Configuration models of business growth and development: A preliminary analytical framework. Proceedings of Nordic InnovationResearch Conference (NIR 2008), 89 Dec., 2008 (1st ed., pp. 1-21). Oulu: University of Oulu.

[129] Munene J. C. (1991). Organizational Environment in Africa: A Factor Analysis of Critical Incidents, Human Relations, 44, 5, 439-458.

[130] Munene, J. C., Schwartz, S. H. and Kibanja, G. (2005). Escaping from Behavioural Poverty in Uganda: The Role of Culture and Social capital. Kampala: Fountain Publishers.

[131] Narayan, D. and Pritchett, L. (1997). Cents and sociability: Household income and social capital in Rural Tanzania (World Bank Policy Research Working Paper No. 1796). 
Innovative Service Delivery and Competitive Advantage of Small Scale Hotels in Nigeria: The Moderating Role of Opportunity Connectedness

[132] Nejati, M., Shahbudin, A.S. and Amran, A. (2010a). Putting sustainability at the core of knowledge management performance evaluation system. IBIMA Publishing, 2010.

[133] Neneh, B. N. and Van Zyl, J. (2017). Entrepreneurial orientation and its impact on firm growth amongst SMEs in South Africa. Problems and Perspectives in Management, Vol. 15(3).

[134] Nogueira, C. G. et al., (2010). The impact of intellectual capital on value added or Brazilian companies traded at the BMF-Bovespa, Journal of International Finance and Economics 10, 2, 1-13.

[135] Nohria, N. and Eccles, R. (1992). Face-to-face: Making network organizations work.

[136] Noorani, I. (2014). Service Innovation and Competitive Advantage, European Journal of Business and Innovation Research, 2(1), 12-38.

[137] Nordman, E. R. and Tolstoy, D. (2016).The impact of opportunity connectedness on innovation in SMEs' foreign-market relationships. Technovation, 57(58), 47-57

[138] Noruzy, A., Dalfard, V. M., Azhdari, B., Nazari-Shirkouhi, S. and Rezazadeh, A. (2012), Relations between transformational leadership. Organizational learning, knowledge management, organizational innovation, and organizational performance: An empirical

[139] Nunnally, J. C. (1978). Psychometric theory. New York: McGraw-Hill.

[140] Nwosu, B. (2008a). In "Nigeria hotels and boom in tourism- by Amadi, O", Business day Newspaper, September 7, 9

[141] Obeidat, B., Al-Suradi, M., Masa'deh, R. and Tarhini, A. (2016). The Impact of Knowledge Management on Innovation: An Empirical Study on Jordanian Consultancy Firms. Management Research Review, 39, 1214-1238.

[142] Obeidat, B., Masa'deh,R. and Abdallah,A. (2014). The Relationship among Human Resource Management Practices, Organizational Commitment, and Knowledge Management Processes: A Structural Equation Modeling Approach, International Journal of Business and Management, 9, 9-26.

[143] Odumeru, J A. (2013). Innovation and organisational performance, Kuwait Chapter of Arabian Journal of Business and Management Review, (2) 12, 18-22

[144] Oghojafor, K. S. (2011), "Empowering Nigeria Youths for National Economic Development: The Role of Entrepreneurship Education”, Journal of Research in National Development, 7(2), 9-17

[145] Okten, C. and Osili, U. (2004). Social networks and credit access in Indonesia, World Development, 32, 1225-1246.

[146] Omoankhanlen, J. A. (2010). Framework for Entrepreneurship Education in Nigerian Higher Institutions of Learning Lwati, Journal of Contemporary Research, 7(1).

[147] Oncioiu, I. (2003). Business Innovation, Development, and Advancement in the Digital Economy. Romania: IGI Global.

[148] Orobia, L. (2013). Social Entrepreneurship - A solution to societal challenges.

[149] Ozgen, E. and Baron, R.A. (2007). Social sources of information in opportunity recognition: Effects of mentors, industry networks, and professional forums, Journal of Business Venturing, 22(2), 174-192.

[150] Papagiannidis, S., Li, F., Erkowitz, H. and Clouse, M. (2009). Entrepreneurial Networks: A Triple Helix Approach for Brokering Human and Social Capital, Journal of International Entrepreneurship, 7(3), 215-235.

[151] Pasban, M. and Nojedeh, S. H. (2016). A Review of the Role of Human Capital in the Organization. Procedia-Social and Behavioral Sciences, 230, 12, 249-253.

[152] Penrose, E. T. (1959a). The Theory of the Growth of the Firm. Oxford University Press: Oxford.

[153] Petty, R. and Guthrie, J. (2001). Intellectual Capital literature review; measurement, reporting and management, Journal for Intellectual Capital, 1(2), 155-176.

[154] Piercy, N.F., Kaleka A. and Katsikeas, C. S. (1998). Sources of competitive advantage in high performing exporting companies, Journal of World Business, 33(4), 378-393.

[155] Pilbeam, S. and Corbridge, M. (2006). People Resourcing - Contemporary HRM in Practice. 3rd ed. Pearson Education Limited. Harlow.

[156] Pojasek, R.B. (2007). A Framework for Business Sustainability, Environ. Quality Management, 17 (2), 81-88.

[157] Porter, M. (1985). Competitive advantage. New York: The Free Press.

[158] Porter, M. E. (Ed.). (1991b). Strategy: Seeking and securing competitive advantage. Boston: Harvard Business School Press

[159] Porter, M. E., Delgado-Garcia, M., Ketels, C. H. M. and Stern, S. (2008) Moving to a New Global Competitiveness Index. In M. E. Porter and K. Schwab (eds.) GlobalCompetitiveness Report 2008/2009, pp. 43-63. Geneva: World Economic Forum. 
Innovative Service Delivery and Competitive Advantage of Small Scale Hotels in Nigeria: The Moderating Role of Opportunity Connectedness

[160] Porter, M.E. (1980b). Industry structure and competitive strategy: Keys to profitability. Financial Analysts Journal, 36(4), 30-41.

[161] Powell, W.W., Koput, K.W. and Smith-Doerr, L. (1996). Interorganizational collaboration and the locus of innovation: Networks of learning in biotechnology, Adm. Sci. Q., 41, 116-145.

[162] Prahalad, C.K. and Hamel, G. (1990), "The core competence of the corporation", Harvard Business Review, 68(3), 79-91.

[163] Qureshi S., Briggs, R. O. and Alupic, V. (2006). Value creation from intellectual capital: convergence of knowledge management and collaboration in the Bandwidth model, Group Decision and Negotiation, 15, 197-220.

[164] Richardson, G.B. (1972). The organisation of industry, The Economic Journal, 82 (Sep), 883-896.

[165] Roth, A. V. and Menor, L. J. (2003). Insights into service operations management: a research agenda, Production \& Operations Management, 12(2): 145-16.

[166] Rosenbusch, N., Brinckmann, J. and Bausch, A. (2011). Is innovation always beneficial? A meta-analysis of the relationship between innovation and performance in SMEs, Journal of Business Venturing, 26(4), 441-457.

[167] Rostek, K. (2012). The reference model of competitiveness factors for SME medical sector, Economic Modellingvol, 29(5), 2039-2048

[168] Rumelt, R. P. (1984). "Towards a Strategic Theory of the Firm," in Richard B. Lamb, ed. Competitive Strategic Management. New Jersey: Englewood Cliffs.

[169] Sambharya, R. B. and Lee, J. (2014) Renewing Dynamic Capabilities Globally: An Empirical Study of the World's Largest MNCs. Management International Review54(2), 137-169.

[170] Sarantakos, S. (2005). Social Research. Palgrave Macmillan. 3rd Ed.

[171] Schumpeter, J. A. (1939). Business Cycles: A Theoretical, Historical, and Statistical Analysis of the Capitalist Process, McGraw-Hill Book Company Inc., New York

[172] Schumpeter, J.A., (1934). The Theory of Economic Development: An Inquiry into Profits, Capital, Credit, Interest and the Business Cycle, translated from the German by Redvers Opie, New Brunswick (U.S.A) and London (U.K.): Transaction Publishers.

[173] Shane, S. (2003). A general theory of entrepreneurship: The individual-opportunity nexus. Edward Elgar: Cheltenham, UK.

[174] Scott, M. and Bruce, R. (1987). Five stages of growth in small business, Long Range Planning, 20(3), 45-52.

[175] Sejjaaka. S. K. (2005). Corporate Mandatory Disclosure practices. Unpublished - PhD thesis. Makerere University, Uganda.

[176] Sekaran, U. (2000) Research Methods for Business: A Skill Business Approach. John Wiley \& Sons, New York.

[177] Serravallo, J. (2015). Reading Strategies Book:Your Everyday Guide to Developing Skilled Readers.

[178] Shamudeen, K., Keat, O. Y. and Hassan, H. (2017). Entrepreneurial Success within the Process of Opportunity Recognition and Exploitation: An Expansion of Entrepreneurial Opportunity Recognition Model, International Review of Management and Marketing, 2017, 7(1), 107-111.

[179] Shapiro, B. P. (1988). what the hell is market oriented? Harvard Business Review, Reprint Service.

[180] Sharif, M. N. (2012). Technological innovation governance for winning the future, Technological forecasting and social change, 79(3), 595-604

[181] Sin, Y; Tse, C; Yau, H; Chow, R; \& Lee, S. (2005). Relationship Marketing Orientation: Scale Development and Cross-Cultural Validation. Journal of Business Research, 58, 185-194.

[182] Slack, N., Chambers, S. and Johnston, R. (2004). Operations Management (4th Edition), Harlow: Pearson Education.

[183] SMEDAN. (2005). Small and medium enterprises performance in Nigeria: A report presented at African entrepreneurship seminar organized in collaboration with the Scientific Committee on Entrepreneurship of the University of Essex. United Kingdom on the 5th of June.

[184] SMEDAN. (2012). Survey report on Micro, Small, and Medium Enterprises (MSMEs) in Nigeria. Abuja: Small and Medium Enterprises Development Agency of Nigeria

[185] Smith, K.G., Collins, C.J., and Clark, K.D. (2005), Academy of management Journal, 48(2), 346-357.

[186] Spender, J.C. (1996), "Making knowledge the basis of a dynamic theory of the firm", Strategic Management Journal, 17(5), 45-62.

[187] Stewart, T. A. (1991), "Intellectual capital", London: Nicholas Brealey Publishing. 
Innovative Service Delivery and Competitive Advantage of Small Scale Hotels in Nigeria: The Moderating Role of Opportunity Connectedness

[188] Stiglitz, J. E. (1990). Peer monitoring and credit markets, The World Bank Economic Review, 4, 351-366.

[189] Subramanian, M and Youndt, M.A. (2005). The influence of intellectual capital on the types of innovative capabilities, Academy of management journal, 48, 450-463.

[190] Teece, D. J., Pisano, G. and Shuen, A. (1997) 'Dynamic Capabilities and Strategic Management', Strategic Management Journal, 18(7), 5091533.

[191] Tether, B. and Howells, J. (2007). Changing understanding of innovation in services, DTI Occasional Paper No. 9: Innovation in Services, Department of Trade and Industry, Manchester.

[192] Thompson, A. A., and Strickland, A. J. (2001). Strategic management: Concepts and cases. Boston, Mass: McGraw-Hill/Irvin.

[193] Tidd, J., Bessant, J. and Pavitt, K. (2007). Řizení inovací. Zavádění technologických, tržních a organizačních změn. Brno: COMPUTER PRESS. 549, 978-80-251-1466-7.

[194] Tierney, P., Farmer, S. M. and Graen, G. B. (1999). An examination of leadership and employee creativity: The relevance of traits and relationships. Personnel Psychology, 52, 591-620.

[195] Timmons, J. and Spinelli, S. (2004). New Venture Strategies: Entrepreneurship for the $21{ }^{\text {st }}$ Century. Burr Ridge, IL: Irwin-McGraw-Hill Publishers.

[196] Ting, D. (2017). Hotel Direct-Booking Pushes Really Worked and Owners Were Big Winners, Skift.

[197] Tolstoy, D. and Agndal, H. (2010). Network resources combinations in the international venturing of small biotech firms. The International Journal of Technology Innovation, Entrepreneurship and Technology Management, 30, 24-36.

[198] Troacă, V. A. and Bodislav, D.A. (2012). Outsourcing. The Concept. Theoretical and Applied Economics, 19(6):51-58.

[199] Tseng, C. Y. and James Goo, Y. J. (2005). Intellectual capital and corporate value in an emerging economy: empirical study of Taiwanese manufacturers, $R \& D$ Management, 35, 2, 187-205.

[200] Udofia, (2011). Constraints to production and sources of nutrients in. NJAFE 28 7(1).

[201] UNCTAD (2002). Reports on the Expert Meetings on Improving Competitiveness of SMEs in Developing Countries: The Role of Finance, including E-finance, to Enhance Enterprise Development. United Nation Council on Trade and Development.

[202] Valliere, D. and R. Peterson (2009). "Entrepreneurship and economic growth: Evidence from emerging and developed countries." Entrepreneurship \& Regional Development, 21 (5-6):459-480.

[203] Van Bastelar, T. (2000). Does social capital facilitate the poor's access to credit? A review of the microeconomic literature. Working paper no.8. Washington, DC: World Bank.

[204] Vanatta, R.B. (2002). Statistical Analysis with Missing Data, 1st ed., Wiley, New York, NY.

[205] Verma, R., Fitzsimmons, J., Heineke, J. and Davis, M. (2002). New issues and opportunities in service design research, Journal of Operations Management, 20(2), 117-120.

[206] Victor, A. C., Dagogo, T. M. and Odunayo, A. O. (2018).Innovation Strategy and Organization Adaptability of Hotels in Port Harcourt, International Journal of Economics and Business Management, 4(1).

[207] Wall, A., Kirk, R. and Martin, G. (2004). Intellectual Capital: Measuring the Immeasurable. Amsterdam: CIMA Publishing.

[208] Wasserman, S. and Faust, K. (1994) Social Network Analysis Methods and Applications. Cambridge University Press, New York.

[209] Welman,C., Kruger,F. and Mitchell, B.(2005). Research methodology, Oxford University Press Southern Africa: Cape Town

[210] Wernerfelt, B. (1984). “A Resource-based View of the Firm,” Strategic Management.

[211] Wilford, D. (2000). What is CRM? Customer Relationship Management, The Times Newspaper, 25 April.

[212] William S Chang, Jasper J Hsieh, (2011) Intellectual Capital and Value Creation-Is Innovation Capital a Missing Link? International Journal of Business and Management, 6(2).

[213] Windahl, C., Anderson, P., Berggren, C. and Nehler, C. (2004). "Manufacturing firms and integrated solutions: characteristics and implications", European Journal of Innovation Management, 7(3), 218-28.

[214] Wood, M.S. and McKinley, W. (2010). The production of entrepreneurial opportunity: A constructivist perspective, Strategic Entrepreneurship Journal, 4(1), 66-84.

[215] Yamane, T. (1973), Statistics: An Introductory Analysis, 3rd ed., Harper \& Row, New York, NY.

[216] Yokoyama, S., \& Ali, A. K. (2006). Social capital and farmer welfare in Malaysia. In International Association of Agricultural Economists Conference. 
Innovative Service Delivery and Competitive Advantage of Small Scale Hotels in Nigeria: The Moderating Role of Opportunity Connectedness

[217] Yusuf, T. O. \& Dansu, F. S. (2013). SMEs, Business Risks and Sustainability in Nigeria, European Journal of Business and Social Sciences, 2(9), 76-94.

[218] Zack, M. H. (1999). Developing a knowledge strategy, California Management Review, 41(3).

[219] Zemplinerová, A. (2010). Inovační aktivita firem a konkurence. Politická ekonomie, 58(6):747-760.

[220] Zhao J, et al. (2017) Molecular basis for the binding and modulation of V-ATPase by a bacterial effector protein. PLoS Pathog. 13(6).

[221] Zikmund, W.G. (2003) Business Research Methods. 7th Edition, Thomson South Western, Ohio.

\section{AUTHORS' BIOGRAPHY}

Cyril, Yiltsen Tsenyil is currently a doctorial student in Strategic Management (studying Outsourcing, Innovative Service Delivery, Absorptive Capacity and Competitive Advantage of SMEs in North Central Nigeria) at University of Jos - Nigeria. He is the Accountant General in Plateau State-Nigeria. His research interest is in strategic management, SMEs transition and SMEs competitiveness.

Professor Samuel, A. Ocholi is a lecturer in the Department of Business Administration, University of Jos-Nigeria. He is currently the Dean, Faculty of Management Sciences, University of Jos. He occupies a competence development niche in Organizational behaviour and Institutional development with an extensive experience in the Public sector, NGO Sector, Public Enterprise/Authority Sector and Private Sector. He has wide publications in reputable journals

Meshach Gomam Goyit is a lecturer in the Department of Business Administration, University of Jos-Nigeria. He is the Head of Department, Business Administration. He obtained his $\mathrm{PhD}$ in University of Jos. His specialization is in Marketing. Service Quality and Profitabilty

Reuel Johnmark Dakung is a lecturer in the Department of Business Administration, University of Jos-Nigeria. He obtained his doctoral degree in entrepreneurship at the Makerere University Business School (MUBS) Kampala, Uganda. His research interest is in strategic management, marketing, entrepreneurship education among the minority groups (disabled students, prison inmates, internally displaced person) and religious entrepreneurship. He is currently the Deputy Director, Center for Entrepreneurship Studies, University of Jos

Citation: Cyril, Yiltsen Tsenyil, et.al. “Innovative Service Delivery and Competitive Advantage of Small Scale Hotels in Nigeria: The Moderating Role of Opportunity Connectedness" International Journal of Managerial Studies and Research (IJMSR), vol 7, no. 6, 2019, pp. 22-42. doi: http://dx.doi.org/10.20431/ 2349-0349.0706003.

Copyright: (c) 2019 Authors. This is an open-access article distributed under the terms of the Creative Commons Attribution License, which permits unrestricted use, distribution, and reproduction in any medium, provided the original author and source are credited. 